\title{
Üçüncü Sektörde Finansal Şeffaflık Sorunu: Türkiye'deki Sivil Toplum Kuruluşlarının Şeffaflık Düzeylerinin İncelenmesi \\ (Financial Transparency Challenge in the Third Sector: Analyzing the Transparency Levels of Non-Governmental Organizations in Turkey)
}

\section{Mehmet Fatih GÜNER (iD) a}

a Alanya Alaaddin Keykubat Üniversitesi, İİBF, Antalya, Türkiye. fatihguner01@gmail.com

\begin{tabular}{|c|c|}
\hline MAKALE BİLGİSİ & ÖZET \\
\hline $\begin{array}{l}\text { Anahtar Kelimeler: } \\
\text { Sivil toplum kuruluşları } \\
\text { Şeffaflık } \\
\text { Finansal şeffaflık } \\
\text { Hesap verebilirlik }\end{array}$ & $\begin{array}{l}\text { Amaç - Üçüncü sektör olarak da isimlendirilen Sivil Toplum Kuruluşları (STK'lar) yürüttükleri } \\
\text { faaliyetler ile önemli bir sosyal fayda sağlamaktadırlar. Finansmanı doğrudan ya da dolaylı olarak } \\
\text { toplum tarafından yapılan STK'ların daha şeffaf olmaları yönünde güçlü bir talep bulunmaktadır. } \\
\text { İnternet siteleri hesap verebilirlik ve şeffaflık aracı olarak uygun bir platform olmasına rağmen STK'lar } \\
\text { özellikle finansal bilgileri paylaşmaktan kaçınmaktadırlar. Bu çalışmanın iki amacı bulunaktadır. } \\
\text { Birincisi STK'ların internet sitelerinde paylaştıkları bilgiler kapsamında merkezi Türkiye'de bulunan } \\
\text { STK'ların şeffaflık düzeylerini saptamaktır. İkincisi STK'ların internet sitelerindeki şeffaflık düzeylerini } \\
\text { etkileyen ana faktörleri belirlemektir. }\end{array}$ \\
\hline $\begin{array}{l}\text { Gönderilme Tarihi } 1 \text { Kasım } \\
2019 \\
\text { Revizyon Tarihi } 18 \text { Aralık } 2019 \\
\text { Kabul Tarihi } 25 \text { Aralık } 2019\end{array}$ & $\begin{array}{l}\text { Yöntem - Merkezi Türkiye'de bulunan } 280 \text { STK'nın internet sitesinden toplanan veriler içerik analizi, } \\
\text { korelasyon ve regresyon analizi ile değerlendirilmiştir. Kurumsal şeffaflık, faaliyet şeffaflığı, finansal } \\
\text { şeffaflık, genel şeffaflık olmak üzere dört düzeyde şeffaflık değerlendirmesi yapılmıştır. Şeffaflık } \\
\text { üzerinde etkisi olup olmadığı araştırılan bağımsız değişkenler ise sırasıyla kurumsal büyüklük, } \\
\text { kurumsal yaş, uluslararası kaynaklardan fon kullanma, SKT türü, faaliyetlerin ulusal-uluslararası } \\
\text { olması ve yönetim kurulu büyüklüğüdür. }\end{array}$ \\
\hline Makale Kategorisi: & $\begin{array}{l}\text { Bulgular - Merkezi Türkiye'de bulunan STK'ların internet sitelerindeki kurumsal şeffaflık düzeyi } \\
\text { yüksek; faaliyet şeffaflığ } 1 \text { orta; finansal şeffaflık düzeyi çok düşük; genel şeffaflık düzeyi düşük } \\
\text { çıkmıştır. Ana hipotez olarak belirlenen STK'ların internet sitelerindeki genel şeffaflık düzeyini, } \\
\text { bağımsız değişkenlerden sadece kurumsal büyüklük etkilemektedir. }\end{array}$ \\
\hline Araştırma Makalesi & $\begin{array}{l}\text { Tartışma - STK'larda en düşük şeffaflık düzeyi finansal şeffaflıkta ortaya çıkmıştır. Kurumsal } \\
\text { büyüklük, uluslararası kaynaklardan fon kullanma ve STK türü hem finansal şeffaflık hem de faaliyet } \\
\text { şeffaflığını etkilemektedir. Finansal şeffaflı̆̆ geliştirecek politikalara odaklanmanın Türkiye'de üçüncü } \\
\text { sektörün büyümesini olumlu etkileyeceği düşünülmektedir. }\end{array}$ \\
\hline
\end{tabular}

\begin{tabular}{l} 
ARTICLE INFO \\
\hline Keywords: \\
Nongovernment organizations \\
Transparency \\
Financial transparency \\
Accountability
\end{tabular}

ABSTRACT

Purpose - Non-Governmental Organizations (NGOs), also called third sector, provide a significant public service through their activities. There has been a strong demand that NGOs, whose funding is done directly or indirectly by the public, be more transparent. NGOs can use websites as a means of accountability and transparency. This research has two aims. The first one is to determine the transparency levels of NGOs in Turkey within the scope of the information that NGOs share on their websites. The second is to identify the determinants affecting transparency levels in NGOs ' websites.

Design/methodology/approach - Data collected from the website of 280 NGOs headquartered in Turkey were evaluated by content analysis, correlation and regression analysis. There have been four Received 1 November 2019 levels of transparency: organizational transparency, activity transparency, financial transparency and overall transparency. The independent variables investigated whether it influences transparency are, respectively, organizational size, organizational age, usage of funds from international sources, type of Revised 18 December 2019 NGOs, executing activities in national-international and board size.

Accepted 25 December 2019

Findings - The organizational transparency level in the websites of NGOs headquartered in Turkey has been high; the activity transparency is moderate; the financial transparency level is very low; and the overall transparency level is low. The overall transparency level of NGOs' websites which is considered as main hypothesis of research is affected only from organizational size among independent variables.

Article Classification:

Research Article
Discussion - The lowest level of transparency in NGOs has emerged in financial transparency. Organizational size, use of funds from international sources, and type of NGO influence both financial transparency and activity transparency. It is thought that focusing on policies that will improve financial transparency will have a positive impact on the growth of the third sector in Turkey.

\section{Önerilen Atıf/ Suggested Citation}

Güner, M. F. (2019) Üçüncü Sektörde Finansal Şeffaflık Sorunu: Türkiye'deki Sivil Toplum Kuruluşlarının Şeffaflık Düzeylerinin İncelenmesi, İşletme Araştırmaları Dergisi, 11 (4), 3245-3255. 


\section{Giriş}

Son zamanlarda Sivil Toplum Kuruluşlarının (STK) toplum içerisindeki görünürlüklerini giderek artmaktadır. Özellikle 1980'li yıllardan sonra, devletlerin kamusal hizmetlerin sunumu, toplumsal refah ve adalet gibi konulardaki açıklarını kapatan STK'lar bu hizmetlerin sunumunda devlete alternatif oluşturmuşlardır (Gazzola, vd., 2019). Bu kuruluşların kamusal hizmetleri fakirlere daha düşük maliyetlere ulaştırdıklarına ve demokratikleşmede etkili olduklarında dair inanç, her ne kadar bunu doğrulayacak araştırmalar olmasa da STK'lara desteği her geçen gün arttırmaktadır (Ebrahim, 2003, s. 813). Eğitim, sağlık, çevre, sosyal hizmetler, siyaset, lobicilik, yardımlaşma gibi çeşitli ve geniş bir alanda faaliyet gösteren STK'lar günümüzde kamu sektörü ve özel sektörden sonra bir ara sektör olarak kabul edilmekte (Gündüz ve Kaya, 2014, s. 132) ve üçüncü sektör olarak isimlendirilmektedir (Güngör, 2019, s. 28).

STK'ların sahip olduğu varlıklar, yönettikleri ekonomik kaynaklar ve istihdam potansiyelleri gerçekten de "üçüncü sektör" olarak tanımlamaya yetecek büyüklüktedir. Örneğin ABD'de yaklaşık olarak 1.561 .000 kuruluşun, yıllık ortalama 2,5 trilyon dolar gelir elde ettiği üçüncü sektör, GSMH'nin \%5,4'ü büyüklügündedir (McKeever, 2018). İtalya'da üçüncü sektör 60 milyar avrodan daha büyük bir ekonomik hacme sahiptir (Gazzola vd., 2019). Türkiye'de ise 170.000 civarında kuruluş (dernek, vakıf, meslek örgütü, sendika ve siyasi parti) aktif olarak faaliyet göstermektedir. Sadece derneklerin 2018 yılı içerisinde elde ettiği gelir 7 milyar dolar civarındadır (STİGM, 2019). Üçüncü sektörün Türkiye GSMH'si içerisindeki payı \%1,34 olarak hesaplanmıştır (Velat, 2015, s. 52). STK'ların ekonomiye diğer bir katkısı ise istihdamdır. Gönüllü katılımcılar dışında on binlerce işgücü STK'larda istihdam edilmektedir. Türkiye'deki STK'larda istihdam edilen personel sayısı 50.000'in üzerindedir (Velat, 2015, s. 52).

Her ne kadar STK'lar projeleri ile sosyal değer yaratmayı amaçlayan kuruluşlar olsalar da bu kuruluşların en temel sorunlardan biri finansman kaynaklarına erişimdir (Gazzola vd., 2019; Paiva ve Carvalho, 2018, s. 31). Kamu sektörünün finansmanı vergiler/diğer kamusal gelirlerle; özel sektörün finansmanı hissedarların sermayeleri ile yapılmaktadır. STK'ların finansmanı ise gönüllülük esasına göre bireyler ve toplum tarafından yapılmaktadır. STK'ların gelir kaynakları bireysel bağışlar, kurumsal bağışlar, devlet tarafından să̆lanan ulusal fonlar, uluslararası kuruluşlardan sağlanan fonlar, üyelik aidatları, kira gelirleri, finansal gelirler, sahip olunan iktisadi işletmelerden elde edilen gelirler gibi kalemlerden oluşmaktadır (Marudas ve Jacobs, 2004, s. 157). Fakat bunlar içerisinde bağışların en önemli gelir kaynağı olduğunu söylemek mümkündür. Bunun farkında olan devletler/hükümetler sivil toplumu güçlendirmek ve üçüncü sektörü büyütmek için çeşitli politikalar geliştirmektedirler. Örneğin bağışların vergiden muaf tutulması gibi. İtalya'da STK'lara yapılan bağışlar, gelirin binde beşine kadar, vergi indirimine konu olabilmektedir (Gazzola vd., 2019). Türkiye'de de kamu yararına faaliyet gösteren derneklere ya da vakıflara yapılan bağışlar, belirli koşullarda kazancın yüzde beşine kadar, vergi indirimine konu olabilmektedir. Bu teşvikler faydalı olmasına karşın asıl odaklanılması gereken konu bağış̧̧ı/destekçi ile STK arasındaki ilişkidir.

Bağış̧̧larla güçlü bir iletişimin varlığı, bağışların devam ettirilmesini sağlayacağından STK'lar için önemlidir. Bu kuruluşlar için yeni bir bağış̧̧ı kazanmanın maliyeti, mevcut bağışçıyı elde tutmanın maliyetinden daha fazladır. Çünkü STK'lar bağış̧̧ının az sayıda olduğu ama yardım/bağış toplayan kuruluş sayısının giderek arttığı rekabetçi bir sektörde faaliyet göstermektedirler (Chad, 2013, s. 10; Wiggil, 2014, s. 280). Başarılı olmak isteyen kuruluşların aralarında bağışçların da yer aldığı tüm paydaşların desteğini kazandıracak politikalar geliştirmesi ve uygulaması gereklidir. Bu bağlamda kamusal desteğin kaybolması bu kuruluşlar açısından en önemli risklerden biridir (Horton, 2015, s. 5). Çünkü kamusal destek ve bağışçların artması üçüncü sektördeki kuruluşların başarısını etkileyen temel unsurlar arasında gösterilmektedir (Gandia, 2011, s. 58). Bağış̧̧̧ların desteğinin devam etmesi ya da artması STK'ların finansal sürdürülebilirlikleri açısından gerekliyken kamusal destek hem finansal açıdan hem da bu kuruluşların faaliyetlerinde yer alacak gönüllülerin temini açısından önemlidir.

\section{Şeffaflik Neden Gerekli?}

Son dönemlerde medyada yer alan ve STK'larda bazı usulsüzlükleri ifşa eden haberler sektöre dair soru işaretlerinin ortaya çıkmasına neden olmaktadır. Olumsuz haberlere örnek olarak kuruluş yöneticilerinin adlarının yolsuzluk iddialarına karışması yöneticilerin yüksek maaşları, etik olmayan yatırımlar, kaynakların amaca uygun kullanılmaması, usulsüzlükler ve finansal tablolarda hilelerin yapılması gösterilebilir (Rodriguez vd., 2012, s. 662; Horton, 2015, s. 4). 
$\mathrm{Bu}$ haberler ve iddialar, toplum tarafından finanse edilen üçüncü sektörde kaynakların doğru kullanılıp kullanılmadığ 1 konusunda tartışmalara neden olduğundan, toplumda STK'ların daha şeffaf olmalarına yönelik talep giderek artmaktadır (McDonnell ve Rutherford, 2018, s. 2). Paydaşların doğru ve yeterli bilgilendirilmesi, bu kuruluşların ihtiyaç duyduğu kamusal desteğin sağlanması açısından gereklidir. Lee ve Joseph'e göre (2013, s. 2218) paydaşların bir kurumu inceleyebilmek ve değerlendirebilmek için gerekli olan bilgilere erişememesi durumunda bilgi asimetrisi oluşmaktadır. Kurumsal hesap verebilirlik ve şeffaflık, STK'lar ile paydaşları arasında oluşan bilgi eksikliği olarak da tanımlanabilecek bilgi asimetrisini ortadan kaldırarak kamusal desteğin güçlendirilmesini sağlamaktadır (Gandia, 2011, s. 59).

Hesap verebilirlik ve şeffaflık STK'lar açısından oldukça önemlidir (Paiva ve Carvalho, 2018, s. 31). Hesap verebilirlik, bir kurumun faaliyetleri ve bunların sonuçları hakkında ilgi duyanları bilgilendirme yükümlülüğü (Yuesti, Novitasari, ve Rustiarini, 2016, s. 102), şeffaflık ise bir kuruluşun faaliyetlerinin ve finansal bilgilerinin kamusal erişime açık olmasıdır (Rodriguez vd., 2012, s. 664). Sadece ulusal bazda değil, küresel ölçekte STK'ların daha şeffaf bir yapıya sahip olması gerektiği yönünde güçlü bir toplumsal talep ve beklenti bulunmaktadır (Wiggil, 2014, s. 278). STK'lar açıkladıkları bilgilerle kaynakların amaçlarına uygun kullanılıp kullanılmadığını göstermeli, bağışçların ve gönüllülerin desteklerini devam ettirmelerini sağlamalıdırlar (Zainon vd., 2014: s. 39). Böylelikle üçüncü sektör kuruluşları varlıklarını devam ettirebilmek için gereksinim duydukları finansman kaynaklarına daha rahat erişebileceklerdir. Çünkü STK'ların bilgi açıklama düzeyleri ya da diğer bir bakış açısıyla STK paydaşlarının finansal bilgilere erişebilmesi, STK'lara yapılan bağışları etkilemektedir (Behn, DeVries, ve Lin, 2010, s. 6; Gandia, 2011, s. 57).

Şeffaflık, geri bildirim ve kurumsal yönetişimin önemli bir aracı olarak kabul edilmektedir (Burger ve Owens, 2010, s. 1263). STK'larda şeffaflığı üç farklı düzeyde incelemek mümkündür (Rodríguez vd., 2012): Kurumsal şeffaflık, faaliyet şeffaflığı ve finansal şeffaflık. Kurumsal şeffaflık, bir örgütün üst yönetim, kilit çalışanlar, organizasyon yapısı ve varsa dahil olduğu ulusal ya da uluslararası ağlara dair bilgilerin kamuoyunun erişimine açık olmasıdır. Faaliyet şeffaflığı, kuruluş tarafından tamamlanmış ya da yürütülen faaliyetlere/projelere dair bütçe, zaman, harcama, proje sorumlusu gibi detaylı bilgilerin kamuya açık olmasıdır. Finansal şeffaflık kuruluşun mali tabloları, denetim raporları gibi dişsal raporlar ile bütçe, muhasebe yönergesi gibi destekleyici/tamamlayıcı belgelerin ve bilgilerin kamuya açık olmasıdır.

STK'ların şeffaflık düzeyleri içerisinde finansal şeffaflığın bariz bir şekilde ayrıştığı görülmektedir. Kurumsal şeffaflık ve faaliyet şeffaflığı çerçevesinde STK'lar bilgi paylaşırken, finansal bilgileri paylaşımında çekingen davrandıkları gözlemlenmektedir. Finansal şeffaflık/raporlama bağlamında uluslararası genel kabul görmüş bir uygulama ya da bir model bulunmadığından STK'larda finansal raporlama standartlarına yönelik bir düzenlemeye ihtiyaç duyulmaktadır (Cordery vd., 2018, s. 2). Çünkü dünyanın farklı yerlerinde, devletler yasal düzenlemeler ile asgari de olsa STK'ları paydaşları ile finansal bilgileri paylaşmaya zorlamaktadır. Buradaki temel amaç toplumsal güveni sağlamak ve yardımlaşma duygusunu artırmaktır. Bu güveni sağlamak için devletler, STK'lardan muhasebe standartlarına göre hazırlanmış yıllık raporlar hazırlamalarını ve paylaşmalarını istemektedirler (McConville ve Cordery, 2018, s. 300). Diğer taraftan STK yöneticileri arasında yapılan araştırmada katılımcıların \%64'ü hesap verebilirliğin odağında finansal konuların yer alması gerektiğini belirtmiş; \%38'i ise hesap verebilirliği finansal şeffaflık olarak tanımlamışlardır (Paiva ve Carvalho, 2018, s. 31). Örneğin ABD'de STK'lar Form 990 adı verilen ve oldukça kapsamlı finansal bilgiler içeren bir formu doldurmak ve internet sitelerinde ilan etmekle yükümlüdürler. Güner (2019, s. 150) ABD'deki Form 990 uygulaması ile Türkiye'de faaliyet gösteren STK'ların bildirim yükümlülüklerini karşılaştırmalı olarak incelediği çalışmasında, ABD'deki uygulamaların Türkiye'ye kıyasla daha kapsamlı bilgiler sunduğu sonucuna ulaşmıştır. İtalya'da, hali hazırda, STK'ları finansal bilgileri paylaşmaya mecbur kılan yasal düzenlemeler bulunmadığından, STK'ların sosyal etkilerine dair bilgilere erişim mümkün değildir (Gazzola vd., 2019). Yasal düzenlemelere uygunluk, kurumsal yönetişim ilkeleri ya da bağış̧̧ların desteğini kazanmak gibi nedenlerden ötürü STK'larda hesap verebilirlik bilinci gelişmekte ve daha şeffaf kuruluş olmak için paydaşlarla bilgi paylaşımları artmaktadır. Bu çerçevede kullanılan en önemli araçlardan biri internet siteleridir.

\section{Yazın taraması}

STK'ların internet siteleri ve STK'larda hesap verebilirlik aracı olarak internet kullanımı yazında çok sık ele alınan konulardan değildir. Özellikle Türkçe yazında çok az sayıda makaleye rastlanmıştır. Bunların 
neredeyse tamamı daha çok halkla ilişkiler/iletişim alanına yönelik araştırmalar olup, paydaş/STK iletişimi üzerine yoğunlaşmıştır. Bu bağlamda Eroğlu (2006) STK'ların tanıtım, iletişim ve bilgi aktarımı konusunda internet sitelerini kullanıp kullanmadıklarını araştırmıştır. Uzunoğlu ve Kip ( 2014) STK'ların sosyal medyaya uyumu ve diyalojik iletişimini incelemişler, Türkiye' de STK internet sitelerinin diyalojik iletişim özelliklerini karşılamadığı sonucuna ulaşmışlardır. Güngör (2019) ise STK'larda diyalojik iletişim konusunu araştırmış Türkiye' de faaliyet gösteren bir kuruluşun internet sitesini detaylı bir şekilde incelemiştir. Özellikle STK'larda hesap verebilirlik ve finansal şeffaflık konusunu araştıran herhangi bir Türkçe çalışmaya rastlanmamıştır.

Uluslararası yazında ise konunun çeşitli açılardan ele alındığı görülmektedir. Finansal raporlamaların gerekliliği (Courtis, 1976) ve finansal açıklamalarda gönüllülük (Cooke, 1989) ile başlayan araştırmalar zorunlu olmayan açıklamaların kurumlara maliyetini ve faydasını konu edinen çalışmalarla (Depoers ve Firth, 2000) devam etmiştir. Başlangıçta sadece özel sektör firmalarını konu alan bu araştırmalar daha sonra STK'ları da kapsamaya başlamıştır. Ebrahim (2003) hesap verebilirliğin STK'larda nasıl uygulandığını incelediği çalışmasında beş temel sistemin/mekanizmanın kullanıldığını ortaya koymuştur. Bunlar sırasıyla, raporlar ve açıklamalar, performans değerlendirme, katılımcılık, öz değerlendirme ve sosyal denetimdir. Oyelere ve diğ. (2003) internetin finansal raporlamada nasıl kullanıldığını incelemiş ve internet kullanımını etkileyen faktörleri araştırmışlardır. Naude ve diğ. (2004) Güney Afrika'daki 10 STK üzerine yaptıkları araştırmada, internet sitelerinin kullanımında iletişim yönteminin ve stratejilerinin, teknik bilgilerden daha önemli olduğu sonucuna ulaşmışlardır. Saxton ve Guo (2011) ABD'de faaliyet gösteren 117 STK'da hesap verebilirlik uygulamalarını araştırmıştır. İnternet sitelerinin iki ölçüte göre, açıklamalar ve diyalog, incelendiği bu araştırma sonuçlarına göre STK'lar interneti daha çok faaliyet sonuçlarını ve finansal bilgilerini paylaşmak için kullanmaktadırlar. Aynı araştırmada aktif büyüklük ile yönetim kurulu performansının STK'larda internet tabanlı hesap verebilirlik uygulamalarını etkileyen iki temel faktör olduğu sonucuna ulaşılmıştır. Diaz ve diğerleri (2013) yaptıkları araştırmada STK'ların internet sitelerini teknik kalite, bilgi kalitesi ve hizmet kalitesi olmak üzere üç grupta incelemişler, internet sitelerinin interaktif tasarlanmadığı bundan dolayı da etkili olmadığı sonucuna ulaşmışlardır. Paiva ve Carvalho, (2018) yaptıkları araştırmada STK'nın türü ile fon kaynaklarının STK'ların paylaştıkları finansal raporlamalar üzerinde etkili olduğunu ortaya koymuşlardır. Rodriguez vd. (2012) STK'ların internet sitelerinde paylaştıkları bilgilerin şeffaflık düzeylerini ölçmüşler ve diğer taraftan da şeffaflığı etkileyen faktörleri araştırmışlardır. Buna göre kurumsal büyüklük, kamudan fon alma ve kuruluşun yaşı şeffaflık düzeyini etkileyen faktörler olarak belirlenmiştir.

$\mathrm{Bu}$ araştırmanın iki temel amacı bulunmaktadır. Birincisi merkezi Türkiye'de bulunan STK'ların internet sitelerinde paylaştıkları bilgilere göre şeffaflık düzeylerinin ne olduğunu ortaya koymaktır. İkincisi ise STK'ların internet sitelerinde paylaştıkları bilgileri/şeffaflık düzeylerini etkileyen faktörleri belirlemektir. Genel olarak internet ve özellikle STK'ların kendi internet siteleri paydaş iletişimi ve bilgi paylaşımı açısından önemli bir araç olarak görülmektedir (Gazzola vd., 2019; Sariene vd., 2018) İnternet sayesinde en güncel ve sınıflandırılmış bilgilere düşük maliyetle ulaşmak ya da bu bilgileri ilgi duyanlara iletmek mümkündür (Rodríguez vd., 2012, s. 664). İnternet sayesinde zaman ve mekâna bağlı olmadan sosyal paydaşlarıyla ilişkiler kurabilen STK'lar çok yönlü paylaşımlar sağlayabilmekte, şeffaflıklarını ve hesap verilebilirliklerini artırabilmektedirler(Güngör, 2019, s. 30).

İnternet siteleri çok önemli bir potansiyele sahip olmasına rağmen STK'ların sadece misyonlarını ve faaliyetlerini paylaştıkları bir iletişim aracı olarak kullanıldığı görülmektedir (Diaz, Blazquez, Molina, \& Consuegra, 2013, s. 371). Kuruluşların çoğu yıllık faaliyet raporlarını/bültenlerini internet sitelerinde paylaşmamakta; kuruluşların politikalarına ve kararlarına dair paylaşılan bilgiler ise genelde şeffaflık ölçütlerini karşılamamaktadır (Yuesti vd., 2016, s. 100). Oysa STK'lar, paydaşları ile kuruluşun bütün faaliyetlerini ve sonuçlarını kapsayan çok boyutlu bir iletişim stratejisi kurmalıdırlar. Çünkü paydaşlar STK'ların kaynakları doğru bir şekilde kullanıp kullanamadığı konusunda nitel ve nicel açılamalar beklemektedirler (Gazzola vd., 2019). Genel olarak, STK'ların daha şeffaf olmalarına yönelik bir talep olsa dahi tıpkı devletler ve özel işletmeler gibi STK'ların da güncel ve detaylı bilgileri paylaşmaktan kaçındıkları görülmektedir (Burger ve Owens, 2010, s. 1263). Bundan ötürü Türkiye'de de STK'ların internet sitelerini çok etkin bir şekilde kullanmadıkları ve bilgi paylaşımının yeteri kadar olmadığı öngörülmektedir.

Hipotez 1: Türkiye'deki STK'ların genel şeffaflık düzeyleri düşüktür. 
Şeffaflık düzeylerini etkileyen çeşitli faktörler vardır. Bu faktörler kurumsal büyüklük, kurumsal yaş, uluslararası kaynaklardan fon kullanma, STK türü, ulusal-uluslararası STK olma ve yönetim kurulu büyüklügüdür (Burger ve Owens, 2010; Saxton ve Guo, 2011; Rodriguez vd. 2012; Murtaza, 2012).

Kurumsal büyüklük: Kurumsal büyüklük şeffaflı̆̆ edilmektedir. Büyük örgütler/kurumlar, küçük örgütlere/kurumlara göre daha fazla ve kapsamlı bilgiler paylaştıklarından, kurumsal büyüklüğün şeffaflık seviyelerini etkilemesi beklenir (Behn vd., 2010, s. 6; Rodriguez vd., 2012). Kurumsal büyüklüğün saptanmasında aktif büyüklük, gelir toplamı, kuruma çalışan gönüllülerin sayısı, kurumda çalışan personel sayısı gibi ölçütler kullanılabilmektedir. Bu araştırmada kurumsal büyüklüğün belirlenmesinde söz konusu STK'nın yönettiği aktif büyüklük ölçüt olarak kullanılmıştır.

Hipotez 2: Kurumsal büyüklük, STK'larda genel şeffaflı düzeyini etkiler.

Yaş: Kuruluşu daha eski olan STK'ların daha yeni kurumlara göre yönetsel araçları daha fazla kullanıyor olması beklenir. Eski STK'lar internet teknolojilerini sadece kendi görünürlüklerini daha da geliştirmek için değil aynı zamanda farklılaştırma stratejisininim bir parçası olarak kullanmalıdırlar (Sariene vd., 2018, s. 71). Bu yüzden de kuruluş tarihi daha eskiye dayanan STK'lar daha fazla bilgiyi internet sitelerinde paylaşırlar. Yaş belirlenirken ilgili STK'nın kuruluş tarihi esas alınır (Saxton \& Guo, 2011).

Hipotez 3: STK'nın yaşı, STK'nın genel şeffaflık düzeyi üzerinde etkilidir.

Uluslararası kaynaklardan Fon Alma: STK'ların çeşitli finansman kaynakları bulunmaktadır. Uluslararası kuruluşlar ya da fonlar bu kaynaklardan biridir. Uluslararası fonlar gerek başvuru öncesinde gerekse başvuru sonrasında STK'ların detaylı bilgi paylaşımlarını zorunlu tutar. Bu yüzden de özellikle uluslararası fonlardan kaynak kullanımı sonrasında STK'ların detaylı raporlar hazırlamaları ve bunları kamuoyu ile paylaşmaları gerekir. Bundan ötürü uluslararası fonları kullanan STK'ların kullanmayan STK'lara kıyasla daha şeffaf olması gerekir.

Hipotez 4: Uluslararası kaynaklardan fon temin etme STK'ların genel şeffaflk düzeyi üzerinde etkilidir.

STK'nın Türü: Türkiye'de STK'lar dernek, vakıf, sendika, siyasi parti ve meslek örgütü çatısı altında örgütlenmektedirler (Güngör, 2019, s. 30). Gerek tabi oldukları mevzuat gerekse finansman kaynaklarına erişim konusunda farklı olduklarından STK'ların türü şeffaflık seviyelerini etkilemektedir. Örneğin sendikaların ve meslek örgütlerinin temel gelirleri üye aidatlarından; siyasi partilerin temel gelirleri ise üye aidatları ve hazine yardımlarından oluşmaktadır. Bazı vakıflar zengin bireylerin ya da şirketlerin (holdinglerin desteği bulunurken bazı vakıflar için dışarıdan gelecek bağışlar çok önemli olabilmektedir. Dernekler ise önemli ölçüde bağışlar ve yardımlarla faaliyetlerini sürdürmektedir. Dış kaynaklara bağımlılık ve mevzuat farklılığından ötürü, STK türünün şeffaflık düzeyini etkilemesi beklenir (Rodriguez vd., 2012).

Hipotez 5: STK türü, STK'nın genel şeffaflı düzeyi üzerinde etkilidir.

Ulusal ya da Uluslararası Olma: STK'ların bir kısmı faaliyetlerini sadece Türkiye'de gerçekleştirirken bir kısmı da hem Türkiye'de hem uluslararası çevrede gerçekleştirmektedir. Uluslararası çalışan STK'ların internet sitelerini daha etkin kullanmaları, bu platformlarda daha fazla bilgi paylaşmaları normaldir. Ayrıca Depoers ve Firth (2000) uluslararasılaşma ile bilgilerin çevrimiçi (internette) paylaşımı arasında doğrudan ve anlamlı bir ilişki olduğunu ortaya koymuştur. Bu yüzden bu araştırmada uluslararası düzeyde çalışan kuruluşların daha şeffaf oldukları kabul edilmektedir.

Hipotez 6: STK'nın uluslararası nitelikte faaliyet göstermesi genel şeffaflı düzeyi üzerinde etkilidir.

Yönetim Kurulunun Büyüklügü: Yönetim kurulunun büyüklüğü ile gerek STK'ların gerekse özel sektör kuruluşlarının bilgi paylaşımları arasında doğrudan bir ilişki bulunmaktadır (Saxton \& Guo, 2011). Çünkü yönetim kurulu üyeleri bilgi paylaşımı ile kuruluşun ününü koruyan bir mekanizma olarak görmektedirler. (Murtaza, 2012). Yönetim kurulunun büyüklügünün saptanmasında yönetim kurulu üye sayısı kullanılmaktadır. Bu çalışmada yönetim kurulu üye sayısı daha fazla olan kuruluşların daha şeffaf oldukları öngörülmektedir.

Hipotez 7: Yönetim kurulu büyüklüğ̈̈ STK'ların genel şeffaflı̆̆ı üzerinde etkilidir. 


\section{Yöntem}

\section{Evren ve Örneklem}

Araştırmada merkezi Türkiye' de kayıtlı olan 280 STK'nın internet sitesinden veri toplanmıştır. Veriler OcakMart 2019 dönemini kapsamaktadır. STK'ların internet siteleri aynı araştırmacı tarafından ziyaret edilmiş ve kapsamlı incelemeler ile veri toplanmıştır. Veri toplanan internet siteleri dernek, vakıf, kamu yararına faaliyet gösteren dernek, kamu yararına faaliyet gösteren vakıf, meslek örgütleri, sendikalar ve siyasi partilerin internet siteleri arasından kurumsal büyüklükleri, kurumsal yaşları göz önünde bulundurularak araştırmacı tarafından rastgele seçilmiştir.

\section{Veri Toplama Araçlar}

Bu çalışmanın temel amacı Türkiye' de faaliyet gösteren STK'ların internet sitelerini bir hesap verebilirlik aracı olarak kullanıp kullanmadıklarını ortaya koymaktır. Bunun için Rodriguez vd.'nin (2012) makalesinde yer alan ölçek/ölçütler seti kullanılmıştır. Bu bağlamda hesap verebilirlik göstergesi olarak "şeffaflık" belirlenmiş ve bir STK için dört şeffaflık seviyesi saptanmıştır: kurumsal şeffaflık, faaliyet şeffaflığı, finansal şeffaflık ve genel şeffaflık. Tablo 1 araştırmada kullanılan ölçeği göstermektedir.

Tablo 1. Şeffaflık Düzeyinin Belirlenmesinde Kullanılan Ölçütler

\begin{tabular}{|c|c|c|c|c|}
\hline & Ölçütler & $\begin{array}{c}\text { Azami } \\
\text { değer }\end{array}$ & $\begin{array}{l}\text { Asgari } \\
\text { Değer }\end{array}$ & $\begin{array}{c}\text { Şeffaflık } \\
\text { Puanı }\end{array}$ \\
\hline \multirow{9}{*}{ 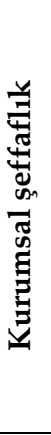 } & Yönetim kurulu ve üst yönetim bilgileri yer almaktadır. & 1 & 0 & 0,91 \\
\hline & Yönetim kurulu üyelerinin ve üst yönetimin özgeçmişleri & 1 & 0 & 038 \\
\hline & Yönetim kurulu/ïst vönetim/calısanların iletisim hiloileri ver & 1 & 0 & 0,38 \\
\hline & almaktadır. & 1 & 0 & 0,43 \\
\hline & Kilit personel bilgileri yer almaktadır. & 1 & 0 & 0,71 \\
\hline & Şubeler ve bağl1 birimler ile ilgili bilgiler mevcuttur. & 1 & 0 & 0,86 \\
\hline & İlişkili taraflar hakkında bilgi var. & 1 & 0 & 0,83 \\
\hline & Kurumsal mevzuat (vakıf senedi, dernek tüzüğ̈̈ vb) var. & 1 & 0 & 0,74 \\
\hline & Kurumsal şeffaflık puanı & 7 & 0 & 0,70 \\
\hline \multirow{7}{*}{ 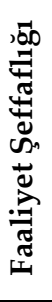 } & Tamamlanmış proje bilgileri var. & 1 & 0 & 0,62 \\
\hline & Yürütülen proje bilgileri var. & 1 & 0 & 0,71 \\
\hline & Proje bilgileri detaylı (yürütücü, takvim,sonuçlar vb) & 1 & 0 & 0,46 \\
\hline & Periyodik raporlar (bülten vb) yayınlanmaktadır. & 1 & 0 & 0,41 \\
\hline & Faaliyet raporu düzenli bir şekilde yayınlanmaktadır. & 1 & 0 & 0,37 \\
\hline & Geleceğe ilişkin raporlar (stratejik plan vb) var. & 1 & 0 & 0,28 \\
\hline & Faaliyet Şeffaflığı Puanı & 6 & 0 & 0,48 \\
\hline \multirow{17}{*}{ 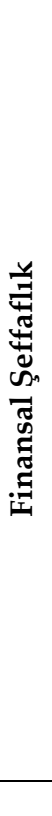 } & Özet bilanço bulunmaktadır. & 1 & 0 & 0,22 \\
\hline & Detaylı bilanço var. & 1 & 0 & 0,19 \\
\hline & Özet gelir tablosu (sadece ana kalemler) var. & 1 & 0 & 0,26 \\
\hline & Gelirler detaylı bir şekilde sınıflandırılmıştır. & 1 & 0 & 0,22 \\
\hline & Yönetime ve çalışanlara yapılan ödemeler ayrıca raporlanmıştır. & 1 & 0 & 0,14 \\
\hline & $\begin{array}{l}\text { Kurumun gerçekleştirdiği projelere ilişkin harcamalar detaylı bir } \\
\text { şekilde gösterilmektedir. }\end{array}$ & 1 & 0 & 0,23 \\
\hline & İlişkili taraflarla yapılan işlemlere yer verilmiştir. & 1 & 0 & 0,19 \\
\hline & Diğer çeşitli finansal raporlar (bütçe, performans değerlendirme vb) & & & \\
\hline & var. & 1 & 0 & 0,07 \\
\hline & Denetleyici kurumlara verilen beyannameler (dernekler beyannamesi & & & \\
\hline & gibi) var. & 1 & 0 & 0,17 \\
\hline & Bağımsız denetim yapıldığı bilgisi/notu var. & 1 & 0 & 0,26 \\
\hline & Bağımsız denetim raporunun bir kopyası internet sitesinde var. & 1 & 0 & 0,11 \\
\hline & $\begin{array}{l}\text { Kurumun etkin bir muhasebe sistemi (yazılı yönerge, çalışan } \\
\text { yetkinliği vb) var. }\end{array}$ & 1 & 0 & 0,18 \\
\hline & Geçmiş dönemlere ait finansal bilgiler var & 1 & 0 & 0,20 \\
\hline & Finansal şeffaflık puanı & 13 & 0 & 0,19 \\
\hline & GENEL ŞEFFAFLIK PUANI & & & 0,45 \\
\hline
\end{tabular}


Şeffaflık seviyelerini etkileyen bağımsız değişkenler ise kurumsal büyüklük, yaş, uluslararası kaynaklardan fon alıp almama, STK türü, ulusal ya da uluslararası olma ve yönetim kurulu büyüklüğü olarak belirlenmiştir.

\section{Verilerin Analizi}

Bu çalışmada iki araştırma sorusu bulunmaktadır. Birincisi Türkiye'deki STK'ların internet sitelerinin şeffaflık düzeylerine dair bir düzey belirleme ve bir görüş ortaya koymaktır. Bu çerçevede Rodriguez vd.'nin (2012) çalışmalarında kullandıkları yöntem tercih edilmiştir. Kurumsal şeffaflık, faaliyet şeffaflığı, finansal şeffaflık üç başlıkta ölçütler/bilgi seti belirlenmiş ve ölçütlerin internet sitesinde yayınlanması durumunda 1, yayınlanmaması durumunda ise 0 puanı verilmiştir. Kurumsal şeffaflıkta 7; faaliyet şeffaflığında 6; finansal şeffaflıkta ise 13 ölçüt bulunmaktadır. Ölçüt sayısı aynı zamanda her bir düzeyin alabileceği maksimum puanı da göstermektedir. Daha sonra puanlar yüzdeye çevrilmiş ve her bir şeffaflık seviyesi yüz birim üzerinden puanlandırılmıştır. Son olarak genel şeffaflık düzeyi adı altında dördüncü bir şeffaflık düzeyi oluşturulmuş, bu seviyenin düzeyi ise kurumsal, faaliyet ve finansal şeffaflık seviyelerinin aritmetik ortalaması ile bulunmuştur.

Çalışmanın ikinci araştırma sorusu STK'ların internet sitelerinde paylaştıkları bilgilere göre belirlenen şeffaflık düzeyini etkileyen faktörlerin değerlendirilmesidir. Bağımsız değişkenlerin arasında anlamlı bir ilişki olup olmadığını belirlemek için korelasyon; STK'larda şeffaflığı etkileyen faktörlerin belirlemek için regresyon analizi kullanılmıştır.

\section{Bulgular}

Tablo 1 üçünü sütunda, STK'larda şeffaflık düzeylerini dört seviyede puanlandırmaktadır. Buna göre internet siteleri incelenen STK'larda üst yönetim bilgileri ve örgütsel yapıya dair bilgilerin paylaşım düzeyini ölçmeye çalışan kurumsal şeffaflık düzeyi \%70 seviyesindedir. Bir STK'nın tamamladığg ya da yürüttüğü faaliyetler ve projelere yönelik internet sitelerinde paylaşılan bilgilerin ölçüldüğü faaliyet şeffaflığı düzeyi \% $48^{\prime}$ dir. STK'lara ait finansal bilgilerin internet sitelerinde paylaşılma düzeylerini ölçen finansal şeffaflık düzeyi \%19 olarak bulunmuştur. Üç şeffaflık düzeyinin bileşimi/ortalaması olan genel şeffaflık düzeyi ise \%45 olarak hesaplanmiştır.

Tablo 2. Bağımsız Değişkenlerin Spearman Korelasyon Matrisi

\begin{tabular}{lcccccc}
\hline & $\begin{array}{c}\text { Kurumsal } \\
\text { büyüklük }\end{array}$ & Kurumsal yaş & Uluslararası fon & STK türü & $\begin{array}{c}\text { Ulusal / } \\
\text { Uluslararası }\end{array}$ & $\begin{array}{c}\text { Yönetim } \\
\text { kurulu } \\
\text { büyüklüğ̈ü }\end{array}$ \\
\hline Kurumsal büyüklük & 1,000 & & & & & \\
Kurumsal yaş &, 085 & 1,000 & & & & \\
Uluslararası fon &,- 089 &,- 053 & 1,000 & & & \\
STK türü &, $317^{* *}$ &,$- 324^{* * *}$ &, 086 & 1,000 & & \\
Ulusal uluslararası &, 129 &, 138 &,$- 408^{* * *}$ &,$- 269^{* *}$ & 1,000 & \\
Yönetim kurulu üye sayısı &,- 051 &,- 059 &,- 053 &, 049 &,- 027 & 1,000 \\
\hline
\end{tabular}

Tablo 2 Spearman korelasyon matrisi bağımsız değişkenlerin aralarında anlamlı bir ilişki olup olmadığını test etmektedir. Sonuçlara göre STK türü ile kurumsal büyüklük arasında ( $\mathrm{r}$ değeri ,317) olumlu yönde düşük düzeyli ilişki; STK türü ile kurumsal yaş arasında ( $\mathrm{r}$ değeri -,324) olumsuz yönde düşük düzeyli ilişki; ulusaluluslararası STK olma ile uluslararası fonlardan kaynak kullanma arasında ( $\mathrm{r}$ değeri -,408) olumsuz yönde düşük düzeyli ilişki; ulusal-uluslararası STK olma ile STK türü arasında ( $r$ değeri -,269) olumsuz yönde düşük düzeyli ilişki belirlenmiştir.

Tablo 3 regresyon analizi sonuçlarını göstermektedir. Regresyon modelinin anlamlılığını kontrol etmek için yapılan testlerde kurumsal şeffaflık için ANOVA testinde F değeri 7,736, R² değeri ,212 ; faaliyet şeffaflığı için ANOVA testinde $\mathrm{F}$ değeri 15,282, $\mathrm{R}^{2}$ değeri ,346; finansal şeffaflık için ANOVA testinde $\mathrm{F}$ değeri $6,573, \mathrm{R}^{2}$ değeri ,186; genel şeffaflık için ANOVA testinde F değeri 3,822, R² değeri ,117 ile anlamlı çıkmıştır. 
Tablo 3. STK'ların İnternet Sitelerindeki Şeffaflık Düzeylerini Etkileyen Faktörler: Regresyon Analizi

\begin{tabular}{|c|c|c|c|c|c|c|}
\hline & & $\mathrm{B}$ & Standart Hata & Beta & $\mathrm{t}$ & $\mathbf{P}$ \\
\hline \multirow{7}{*}{ 宽 } & Sabit & 1,577 & 160 & & 9,886 & ,000 \\
\hline & Kurumsal büyüklük &,- 057 & ,022 &,- 185 & $-2,540$ & ,012 \\
\hline & Kurumsal yaş &,- 002 & ,001 &,- 240 & $-3,280$ & ,001 \\
\hline & Uluslararası fon & 071 & ,051 & ,103 & 1,382 & 169 \\
\hline & STK türü & ,013 & ,015 & 070 & ,911 & ,363 \\
\hline & Ulusal uluslararası &,- 079 & ,076 &,- 080 & $-1,046$ & ,297 \\
\hline & Yönetim kurulu büyüklüğü &,- 017 & ,005 &,- 248 & $-3,620$ &, 000 \\
\hline \multirow{7}{*}{ 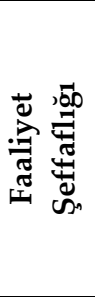 } & Sabit & 3,011 & 607 & & 4,963 & ,000 \\
\hline & Kurumsal büyüklük & ,447 & ,085 & ,350 & 5,275 & , 000 \\
\hline & Kurumsal yaş & 001 & ,003 & 024 & 364 & ,716 \\
\hline & Uluslararası fon &,- 975 & 195 &,- 339 & $-5,007$ & , 000 \\
\hline & STK türü &,- 187 & ,056 &,- 233 & $-3,340$ & ,001 \\
\hline & Ulusal uluslararası & ,268 & 287 &, 065 & ,932 & ,353 \\
\hline & Yönetim kurulu büyüklüğü & 047 & ,018 & 166 & 2,652 & ,009 \\
\hline \multirow{7}{*}{ 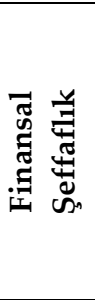 } & Sabit & 1,268 & 194 & & 6,521 & ,000 \\
\hline & Kurumsal büyüklük &,- 061 & ,027 &,- 165 & $-2,232$ & ,027 \\
\hline & Kurumsal yaş & 001 & ,001 &, 004 & ,057 & ,955 \\
\hline & Uluslararası fon & ,300 & ,062 & ,364 & 4,810 & ,000 \\
\hline & STK türü & ,042 & ,018 & 180 & 2,315 & ,022 \\
\hline & Ulusal uluslararası & 067 & ,092 & ,057 & ,726 & ,469 \\
\hline & Yönetim kurulu büyüklüğü &,- 007 & ,006 &,- 081 & $-1,160$ & ,248 \\
\hline \multirow{7}{*}{ 离 } & Sabit & 1,754 & 119 & & 14,686 & ,000 \\
\hline & Kurumsal büyüklük & ,057 & ,017 & 264 & 3,427 & ,001 \\
\hline & Kurumsal yaş & 000 & ,000 &,- 052 &,- 678 & ,499 \\
\hline & Uluslararası fon &,- 055 & ,038 &,- 114 & $-1,444$ & 151 \\
\hline & STK türü &,- 019 & ,011 &,- 139 & $-1,716$ & ,088 \\
\hline & Ulusal uluslararası & 073 & ,057 & ,106 & 1,297 & ,196 \\
\hline & Yönetim kurulu büyüklüğü & ,003 & ,003 &, 062 & ,851 & ,396 \\
\hline
\end{tabular}

Regresyon analizi sonuçlarına göre kurumsal büyüklük, kurumsal yaş ve yönetim kurulu büyüklüğü kurumsal şeffaflık düzeyini etkilemektedir. Faaliyet şeffaflığı, kurumsal büyüklük, uluslararası kaynaklardan fon kullanma, STK türü ve yönetim kurulu büyüklüğü bağımsız değişkenlerinden etkilenmektedir. Finansal şeffaflı̆̆ı etkileyen bağımsız değişkenler ise kurumsal büyüklük, uluslararası kaynaklardan fon kullanma ve STK türüdür. STK'larda genel şeffaflık düzeyini ise sadece kurumsal büyüklük etkilemektedir.

\section{Sonuç ve Tartışma}

Bu araştırmanın birinci amacı Türkiye' de finansal şeffaflık düzeyini belirlemektir. Bu çerçevede birinci hipotez olarak "Türkiye'deki STK'ların genel şeffaflık düzeyleri düşüktür" önermesi belirlenmiştir. Tablo 1'de detayları görüleceği üzere STK'ların genel şeffaflık düzeyi \% $45^{\prime}$ tir. Aynı yöntem ve ölçek ile İspanya'da yürütülen araştırma sonuçlarına göre, İspanyol STK'larda genel şeffaflık düzeyi \%30 olarak belirlenmiştir (Rodriguez vd., 2012). Her ne kadar Türkiye'deki STK'ların şeffaflık puanları İspanya' daki muadillerine göre daha yüksek olsa da \%50'nin altında olduğundan düşük olarak değerlendirilmektedir. Hipotez 1 kabul edilmiştir. Genel şeffaflı̆̆ın detayları incelendiğinde STK'ların üst yönetim, örgütsel yapı şubeler ve kilit personel gibi kurumsal bilgilerini paylaşmakta bir sakınca görmedikleri anlaşılmaktadır. Tamamlanmış ve yürütülen faaliyetlerde de orta düzeye yakın konumlandırılabilecek bir seviye, \%48, görülmektedir. Temel sorun finansal şeffaflık düzeyinde ortaya çıkmaktadır. Türkiye'deki STK'lar finansal bilgileri sadece \%19 düzeyinde paylaşmaktadırlar. Ayrı bir araştırma konusu olabilecek bu sorunun ortaya çıkmasına, yöneticilerin finansal şeffaflığın önemi hakkında bilgi sahibi olmamaları, finansal şeffaflığa dair yasal düzenlemelerin olmaması, finansal bilgilerin gerek STK'lar gerekse yöneticiler hakkında yeni tartışmalara yol açması, STK yöneticilerinin hesap vermekten kaçınmaları gibi nedenlerin etkili olduğu düşünülmektedir.

Araştırmanın ikinci amacı STK'ların internet sitelerindeki şeffaflık düzeylerini etkileyen faktörlerin neler olduğunu ortaya koymaktır. Bu çerçevede altı bağımsız değişken belirlenmiş ve bunların şeffaflık üzerinde etkisi olduğuna dair hipotezler geliştirilmişti. Regresyon analizi sonuçları biri genel üçü de alt seviye olmak üzere dört ayrı seviyede incelenmiştir. Araştırma sorusu genel şeffaflık düzeyinde cevaplanmakla birlikte alt 
seviye şeffaflık düzeyleri STK'ların hesap verebilirliğe nasıl yaklaştıkları konusunda önemli bilgiler vermektedir. Genel şeffaflık düzeyine göre bağımsız değişkenlerden sadece kurumsal büyüklük STK'ların şeffaflık kararlarını etkilemektedir. Bu sonuç yazında Saxton ve Gou (2011) ile Rodriguez vd. (2012) sonuçları ile uyumludur. Hipotezlerden sadece Hipotez 2 kabul edilmiş, diğer hipotezler ise reddedilmiştir. Bununla birlikte alt seviye şeffaflık düzeylerini değerlendirmek, hipotezlerin neden reddedildiğini ortaya koymak açısından gereklidir.

Birinci alt seviye şeffaflık düzeyi kurumsal şeffaflık olup bu seviyede yönetim kurulu üyeleri ve kuruluşun üst yöneticileri hakkında bilgiler, iletişim bilgileri, kuruluşun dahil olduğu ağlar ve uluslararası ilişkiler gibi konuların internet sitelerinde paylaşılıp paylaşılmadığı araştırılmıştır. Kurumsal şeffaflığın, kurumsal büyüklük, kurumsal yaş ve yönetim kurulu büyüklüğünden etkilendiği görülmektedir. Kurumsal şeffaflık düzeyi aynı zamanda şeffaflık endeksinden de yüksek puan almıştır. İki sonuç birlikte değerlendirildiğinde Türkiye'de STK'ların kurumsal şeffaflık bağlamında bilgi paylaşım düzeyinin yüksek olduğu görülmektedir. Büyük ve eski (kuruluş tarihine göre) STK'ların genelde yönetim kurulu üye sayılarının küçük ve genç STK'lara göre daha fazla olduğu gözlemlenmiştir. Bu sonucun beklenen bir sonuç olduğu söylenebilir.

İkinci alt seviye şeffaflık düzeyi faaliyet şeffaflı̆̆ıdır. Bu düzeyde STK'ların internet sitelerinde tamamladıkları ve yürüttükleri projeler, faaliyetler ve bunların sonuçları hakkında detaylı bilgiler paylaşıp paylaşmadıkları ve STK hakkında bilgi veren periyodik raporlar yayınlayıp yayınlamadıkları araştırılmaktadır. Faaliyet şeffaflı̆̆ını etkileyen bağımsız değişkenler kurumsal büyüklük, uluslararası kaynaklardan fon kullanma, STK türü ve yönetim kurulu büyüklügüdür. Bu bağımsız değişkenlerden özellikle ikisi, uluslararası kaynaklardan fon kullanma ve STK türü, dikkat çekicidir. Bu iki bağımsız değişken üçüncü alt seviye şeffaflık düzeyi olan finansal şeffaflı̆̆ı da etkileyen faktörler olduklarından, faaliyet şeffaflı̆̆ına ve finansal şeffaflığına etkileri birlikte değerlendirmek gerekir. Uluslararası kaynaklardan fon kullanan STK'lar gerek içsel gerekse dişsal raporlarla paydaşları bilgilendirmektedirler. Fon dağıtan kuruluşlar, STK'ları hesap verebilirlik kapasitelerini geliştirmeye ve kurumsal yönetişim ilkelerini uygulamaya teşvik etmektedir. Bunun sonucu olarak özellikle uluslararası kaynaklardan fon temin eden STK'ların internet sitelerinde daha detaylı bilgilerin yer aldığı, internet sitelerinin daha profesyonel hazırlandığı, faaliyet bilgilerinin yanında finansal bilgilere yeterli derecede yer verildiği, veri toplama aşamasında gözlemlenmiştir. Diğer taraftan STK türü de faaliyet şeffaflığı ile finansal şeffaflığı etkilemektedir. Özellikle dernekler ve vakıfların bir kısmı (holding vakfı ya da arkasında zengin bir aile/bireyin olmadığı vakıflar) gibi dış kaynaklara gereksinim duyan STK'ların daha fazla bilgi paylaşımında bulunduğu gözlemlenmiştir. Sendika, meslek örgütü ya da siyasi parti gibi gelirleri daha çok üye aidatlarına ya da kamusal fonlara dayanan STK'larda bilgi paylaşımının sınırlı olduğu gözlemlenmiştir. Hatta sendika internet sitelerinde finansal bilgilere hiç yer verilmediği ve siyasi parti internet sitelerinde finansal bilgilere çok az yer verildiği gözlemlenmiştir. STK'ların önemli bir kısmında hesap verebilirliği sadece denetleyici kamu idaresi ile sinırlı tuttukları, bilgilendirmelerini sadece yasal yükümlükler kadar yerine getirdikleri söylenebilir. Şöyle ki dernekler, "dernekler beyannamesi" adlı bir form düzenlemek ve denetleyici kamu idaresi olan İçişleri Bakanlı̆̆ Sivil Toplumla İlişkiler Genel Müdürlüğüne ibraz etmek zorundadırlar. Dernekler mevzuata göre bu beyannameyi internet sitelerinde de ilan etmek zorunda olmalarına karşın, herhangi bir kontrol ya da yaptırım olmadığı için, internet sitelerinde yayınlamamaktadırlar. Oysa Kemp ve Morgan'a göre (2018, s.1) denetleyici kamu idarelerine verilen beyanların yayınlaması güzel bir hesap verebilirlik örneğidir. Bu bağlamda Türkiye'deki derneklerin sadece dernekler beyannamesinin internet sitelerinde yayınlanması bile STK'ların internet sitelerindeki şeffaflık düzeyini oldukça yüksek düzeylere çıkaracaktır.

Gelişmiş ülkelerde ülke GSMH'sinin \%5'i büyüklüğünde olan üçüncü sektör Türkiye'de GSMH'nin \%1,5'u düzeyindedir. Ülkemizde üçüncü sektörün büyüyebileceği bir alan bulunmaktadır. Bunun için sivil toplum paydaşlarının güvenini kazanmak ve katılımcılık düzeyini artırmak gerekmektedir. Şeffaflık ve hesap verebilirlik önemli bir araç olarak üçüncü sektörün büyümesine katkıda bulunabilir. Araştırma sonucunda, şeffaflık bağlamında STK'ların finansal bilgilerini paylaşmaktan kaçındıkları, finansal şeffaflığın çok düşük olduğu sonucuna ulaşılmıştır. Bu yüzen de finansal şeffaflığı engelleyen faktörlerin araştırılması, finansal şeffaflığı teşvik edecek ve STK'ları finansal şeffaflığa zorlayacak yasal düzenlemelerin hayata geçirilmesi önemlidir. 


\section{Kaynakça}

Behn, B. K., DeVries, D. D., ve Lin, J. (2010). The determinants of transparency in nonprofit organizations: An exploratory study. Advances in Accounting, 26(1), 6-12. https://doi.org/10.1016/j.adiac.2009.12.001

Burger, R., ve Owens, T. (2010). Promoting Transparency in the NGO Sector: Examining the Availability and Reliability of Self-Reported Data. World Development, 38(9), 1263-1277. https://doi.org/10.1016/j.worlddev.2009.12.018

Chad, P. (2013). Extending the use of market orientation: Transforming a charity into a business. Australasian Marketing Journal (AMJ), 21(1), 10-16. https://doi.org/10.1016/j.ausmj.2012.08.003

Cordery, C. J., Crawford, L., Breen, O. B., ve Morgan, G. G. (2018). International practices, beliefs and values in not-for-profit financial reporting. Accounting Forum. https://doi.org/10.1016/j.accfor.2018.05.001

Cooke, T. E. (1989). Voluntary corporate disclosure by Swedish companies. Journal of International Financial Management \& Accounting, 1, 171-195

Courtis, J. K. (1976). Relationships between timeliness in corporate reporting and corporate attributes. Accounting and Business Research, 6, 45-56.

Depoers, F., ve Firth, M. (2000). A Cost Benefit Study of Voluntary Disclosure: Some Empirical Evidence From french listed Companies. The European Accounting Review, 9(2), 245-263.

Diaz, E., Blazquez, J., Molina, A., ve Consuegra, D. (2013). Are the Nongovernmantls Organizations' Websites Effective? Qualitative Market Research: An International Journal, 16(4), 370-392.

Ebrahim, A. (2003). Accountability In Practice: Mechanisms for NGOs. World Development, 31(5), 813-829.

Gandia, J. (2011). nternet disclosure by nonprofit organizations: Empirical evidence of nongovernmental organizations for development in Spain. Nonprofit and Voluntary Sector Quarterly, 40(1), 57-78.

Gandia, J. L. (2011). Internet Disclosure by Nonprofit Organizations: Empirical Evidence of Nongovernmental Organizations for Development in Spain. Nonprofit and Voluntary Sector Quarterly, 40(1), 57-78. https://doi.org/10.1177/0899764009343782

Gazzola, P., Amelio, S., Papagiannis, F., ve Michaelides, Z. (2019). Sustainability Reporting Practices and Their Social Impact to NGO Funding in Italy. Critical Perspectives on Accounting. https://doi.org/10.1016/j.cpa.2019.04.006

Gündüz, A. Y., ve Kaya, M. (2014). Küresel dünyada sivil toplum kuruluşlarının ekonomik kalkınmadaki rolleri üzerine bir değerlendirme. Akademik Araştırmalar ve Çalışmalar Dergisi (AKAD), 6(10). https://doi.org/10.20990/aacd.20991

Güner, M. F. (2019). Sivil Toplum Kuruluşlarında Finansal Şeffaflık: Türkiye ve ABD Uygulamalarının Karşılaştırılması. Uluslararası Sosyal, Beşeri ve İdari Bilimler Sempozyumu (s. 150-163). Alanya: ASOS .

Güngör, F. S. (2019). Diyalojik İletişim ve Sivil Toplum Örgütlerinin Web Siteleri: Cumhuriyetin İlk Sivil Toplum Kuruluşu "Türkiye Yardım Sevenler Derneği" Web Sitesi Değerlendirmesi. Başkent Üniversitesi Ticari Bilimler Fakültesi Dergisi, 3(2), 25-43.

Horton, R. (2015). Transparency and Trust in the Charity Industry (ss. 1-23). Centre for Social Innovation University Of Cambridge.

Kemp, J. H., ve Morgan, G. G. (2018). Incidence and perceptions of "qualified" accounts filed by small charities. Accounting Forum. https://doi.org/10.1016/j.accfor.2018.07.003

Lee, R. L., ve Joseph, R. R. (2013). An examination of web disclosure and organizational transparency I Elsevier Enhanced Reader. Computers in Human Behavior, 29, 2218-2224. https://doi.org/10.1016/j.chb.2013.05.017

Marudas, N. P., ve Jacobs, F. A. (2004). Determinants of Charitable Donations to Large U.S. Higher Education, Hospital, and Scientific Research NPOs: New Evidence from Panel Data. Voluntas: International Journal 
M. F. Güner 11/4 (2019) 3245-3255

$\begin{array}{lllll}\text { of Voluntary ve Nonprofit } \quad \text { Organizations, } & 15(2), & \text { 157-179. }\end{array}$ https://doi.org/10.1023/B:VOLU.0000033179.47685.1c

McConville, D., ve Cordery, C. (2018). Charity performance reporting, regulatory approaches and standardsetting. Journal of Accounting and Public Policy, 37(4), 300-314. https://doi.org/10.1016/j.jaccpubpol.2018.07.004

McDonnell, D., ve Rutherford, A. C. (2018). Promoting charity accountability: Understanding disclosure of serious incidents. Accounting Forum. https://doi.org/10.1016/j.accfor.2018.05.003

McKeever, B. S. (2018, 12 13). The Nonprofit Sector in Brief 2018: Public Charites, Giving, and Volunteering. Urban Institute: https://nccs.urban.org/publication/nonprofit-sector-brief-2018\#the-nonprofit-sector-in-brief2018-public-charites-giving-and-volunteering adresinden alınd1

Murtaza, N. (2012). Putting the Lasts First: The Case for Community-Focused and Peer-Managed NGO Accountability Mechanisms. VOLUNTAS: International Journal of Voluntary and Nonprofit Organizations, 23(1), 109-125. https://doi.org/10.1007/s11266-011-9181-9

Naudé, A., Froneman, J. ve Atwood, R. (2004). The Use of the Internet by Ten South African NonGovernmental Organizations - A Public Relations Perspective, Public Relations Review, (30) 87-94.

Oyelere, P., Laswad, F., \& Fisher, R. (2003). Determinants of internet financial reporting by New Zealand companies. Journal of International Financial Management \& Accounting, 14(1), 26-63.

Paiva, I., ve Carvalho, L. (2018). Accounting and Management Practices in the Third Sector in Angola. 11(3), 15.

Rodriguez, M. del M. G., Caba Pérez, M. del C., ve López Godoy, M. (2012). Determining Factors in Online Transparency of NGOs: A Spanish Case Study. VOLUNTAS: International Journal of Voluntary and Nonprofit Organizations, 23(3), 661-683. https://doi.org/10.1007/s11266-011-9229-x

Sariene, L. S., Rodriguez, M. M., ve Rosario, A. H. (2018). Exploring Determining Factors of Web Transparency in the World's Top Universities. Spanish Accounting Review, 21(1), 63-72. https://doi.org/10.1016/j.rcsar.2017.07.004

Saxton, G. D., ve Guo, C. (2011). Accountability Online: Understanding the Web-Based Accountability Practices of Nonprofit Organizations. Nonprofit and Voluntary Sector Quarterly, 40(2), 270-295.

STIGM. (2019, 10 24). STK'lara İlişkin İstatistikler. Sivil Toplumla İlişkiler Genel Müdürlüğü: https://www.siviltoplum.gov.tr/derneklere-ait-gelir-toplamlari adresinden alındı

Uzunoğlu, E., ve Misci Kip, S. (2014). Building relationships through websites: A content analysis of Turkish environmental non-profit organizations' (NPO) websites. Public Relations Review, 40(1), 113-115. https://doi.org/10.1016/j.pubrev.2013.06.001

Velat, D. (2015). Batı Balkanlar ve Türkiye'de STK'ların Ekonomik Değerleri. Belgrad: Balkan Sivil Toplumu Geliştirme A $\breve{g}$.

Wiggil, M. N. (2014). Donor relationship management practices in the South African non-profit sector. Public Relations Review, 40, 278-285. https://doi.org/10.1016/j.pubrev.2013.10.005

Yuesti, A., Novitasari, L. G., ve Rustiarini, N. W. (2016). Accountability of Non-Government Organization from the Perspective of Stakeholder Theory. International Journal of Accounting and Taxation, 4(2). https://doi.org/10.15640/ijat.v4n2a7

Zainon, S., Atan, R., Wah, Y. B., ve Ahmad, R. A. R. (2014). Informatıon disclosure by charıty organızatıons. Recent Advances in Business Administration, 6. 